\title{
Book Notes
}

Dirk Hoerder, ed. Plutocrats and Socialists: Reports by German Diplomats and Agents on the American Labor Movement 1878-1917. H.G. Saur, Miinchen. 1981. 422 pp.

American Studies scholars are increasingly discovering European sources. A recent contribution to our understanding both of American history and of the importance of making European source material available is Dirk Hoerder's presentation of reports on the American labor movement by German diplomats and agents from the archives of both German republics. Apart from a 75 page edited version of a report prepared for the German Chancellor by a Professor Carl Abel after a visit to the US in 1893, the book presents extracts from a large number of reports chronologically and thematically organized in the context of a useful historical commentary. This serves two purposes: it is easy to find how specific events or issues are dealt with in these reports and they may be read as part of an over-all historical narrative.

The reports and their context are given in German while an extremely useful' 115 page appendix, with a comparative chronology, a glossary, charts, etc. is. in English.

Dirk Hoerder has made new source material available to historians, but alsa written a book that should prove a useful text in graduate seminars either on the 1865-1917 period or on labor history.

2

Peter Snow, Comp., The United States: a Guide to Library Holdings in the UK. The British Library Lending Division. 1982. 717 pages.

In Britain Peter Snow and the Advisory Committee on American Studies. of the Standing Conference of National and University Libraries have since 1978 been providing essential tools for American Studies scholars. This volume should be particularly useful for scholars preparing a visit to the United Kingdom.

The following quotation from the publishers' promotion leaflet is an apt description of Mr Snow's work and should give a good indication of its usefulness :

The United States: a guide to library holdings in the United Kingdom is the outcome of a year's survey of library holdings, sponsored by the US Government through SCONUL and carried out by questionnaire and by some 140 extended visits to libraries. It is intended to provide three kinds of information: about the holdings of a library or of libraries in a given area; about resources on a particular subject; and locations of certain large and important items. 
Over 720 pages long, it describes the holdings of more than 350 libraries of all types in the United Kingdom, in subjects of relevance to the study of the United States: history, literature, the arts and social sciences, business and the history of science and technology. A detailed account is also given of the conditions, facilities and services of each of the libraries concerned. There is an annex of over 1800 large items with library locations for: microform collections; printed collections, collected works and papers; colonial, federal and state documents; law reports; bibliographies and indexes; reference works; atlases and maps; audio-visual materials. A detailed index of some 80 pages is also provided.

Rob Kroes, Ed., European Contributions to American Studies I-IV. Amerika Instituut, University of Amsterdam (lor the Netherland's American Studies Association). 1979-1981.

The proliferation of publications is one indication of the growth of scholarly American Studies in Europe. But far more interesting than this quantitative manifestation of the strength of the discipline is the confidence of full participation in a truly international community of scholars that emanates from so many of these pages. From an early state of grand ignorance of American scholarship to a dependence on American initiatives, European students of the US now seem to have cut off their umbilical cords and are developing their own approaches to and theories of American Studies.

The newly organized Netherlands' American Studies Association has published four volumes in as many years of its series European Contributions to American Studies, edited by the social scientist Rob Kroes of Amsterdam University's Amerika Instituut.

Dr. Kroes has put his own stamp of quality on these volumes not merely as editor but in his own essays that contribute significantly to the thematic unity of each volume. These volumes are:

\section{American Immigration = Its Variety and Lasting Imprint}

II The Intellectual in America

III The American Identity = Fusion and Fragmentation

IV Image and Impact: American Influences in the Netherlands Since 1945

Volume III is of special interest as it presents the papers of the Biennial Conference of the European Association for American Studies in Amsterdam, 1980. The different approaches of Werner Sollors (Columbia) and Willi Paul Adams (Berlin) to the Melting Pot concept speak for the variety so important for the vitality of American Studies, while John G. Blair (Geneva) discusses new methods and approaches to the interdisciplinary study of the US in his suggestive essay on "Interchangeable Parts and the Organization of Life in the United States." 
Marta Sienicka, ed., Traditions in the Twentieth Century American Literature. Adam Mickiewicz University, Poznan. 1981. (Seria Filologia Angielska nr. 16.)

Poland is one of many European countries where there is little relationship between the excellence of American Studies scholarship and its availability to the international community of scholars. Two trends are changing this state of affairs as far as Poland is concerned: an increasing number of articles and books are published in English, and several successful international scholarly conferences have been held in Poland in recent years. Two of these conferences have been hosted by the Adam Mickiewicz University of Poznan and their success has to a great extent been due to the indefatigable work of Dr. Marta Sienicka. This volume presents the papers of the most recent of these conferences.

A majority of the 9 (of 21) Polish contributions are on contemporary American writers (Gaddis, Gardner, Ammons, Pynchon, Gass, and Barthelme). However, there are also solid contributions to historical scholarship and criticism by the Warsaw scholars Teresa Kieniewicz (on "the Concept of Success for Women in the 1870's and 1880's") and Zbigniew Lewicki (on the "American Apocalyptic Tradition").

О.Ø. 


\section{Books.Received}

Winfried Fluck, Jurgen Peper, Willi Paul Adams, eds., Forms and Functions of History in American Literature: Essays in Honor of Ursula Brumm. Erich Schmidt Verlag. Berlin. 1981.

D.K. Adams, S.F. Mills, H.B. Rodgers, An Atlas of North American Affairs. Second Edition. Methuen. London and New York. 1979.

R.C. Simmons, The American Colonies = From Settlement to Independence. (Paperback reprint). Longman. Harlow, Essex. 1981.

Carl Bridenbaugh, Early Americans. Oxford U.P. New York and Oxford. 1981.

James Axtell, ed., The Indian Peoples of Eastern America: A Documentary History of the Sexes. Oxford U.P. New York and Oxford. 1981.

Thomas C. Cochran, Frontiers of Change: Early Industrialism in America. Oxford U.P. New York and Oxford. 1981.

Eric Foner, Politics and Ideology in the Age of the Civil War. Oxford U.P. New York and Oxford. 1980.

Janet Sharp Hermann, The Pursuit of a Dream. Oxford U.P. New York and Oxford. 1981.

Linda O. McMurry, George Washington Carver: Scientist and Symbol. Oxford U.P. New York and Oxford. 1981.

David Brody, Workers in Industrial America: Essays on the Twentieth Century Struggle. Oxford U.P. New York and Oxford. 1980.

Mario T. Garcia, Desert Immigrants: The Mexicans of El Paso, 1880-1920. (Yale Western Americana Series, 32.) Yale U.P. New Haven and London. 1981. 